\title{
Coffee rust regains foothold
}

Researchers marshal technology in bid to thwart fungal outbreak in Central America.

\section{BY DANIEL CRESSEY}

$\mathrm{W}$ here there is coffee, there is 'coffee rust'. But the long stalemate between growers and the fungus behind the devastating disease has broken with the fungus taking the advantage. As one of the most severe outbreaks ever rages through Central America, researchers are reaching for the latest tools in an effort to combat the pest, from sequencing its genome to cross-breeding coffee plants with resistant strains.

Caused by the fungus Hemileia vastatrix, coffee rust generally does not kill plants, but the Institute of Coffee of Costa Rica estimates that the latest outbreak may halve the 2013-14 harvest in the worst affected areas of the nation. This outbreak is "the worst we've seen in Central America and Mexico since the rust arrived" in the region more than 40 years ago, says John Vandermeer, an ecologist at the University of Michigan in Ann Arbor, who has received "reports of devastation in Nicaragua, El Salvador and Mexico".

At his research plot in Mexico, Vandermeer says that the situation is so bad that the leaves are simply dropping off the plants. More than $60 \%$ of the trees have at least $80 \%$ defoliation, and $30 \%$ have no leaves at all.

On 22 January, Costa Rica enacted emergency legislation to speed up the flow of government money towards fighting the fungus. Other nations are also stepping up the fight. Last week, the Nicaraguan government reportedly declared that it would include coffee rust on a list of special research projects designed to safeguard the country's agriculture.

The fungus first emerged as a significant problem by 1869 in Ceylon — now Sri Lanka - before spreading around the world. Stuart McCook, a historian at the University of Guelph in Canada who studies the rust, says that the wet weather in some areas of Ceylon was ideal for the spread of the fungus, and more than $90 \%$ of coffee crops were wiped out in those regions. Faced with an economic catastrophe, the country abandoned coffee for the tea it is associated with today. The disease is so universal that it "is not going to be eradicated; or the only way to eradicate the disease in

O NATURE.COM Read about efforts to produce caffeinefree coffee strains: go.nature.com/m5e66i practice is to eradicate all of the coffee", says McCook.

By 1970, the fungus had been detected in Brazil, and

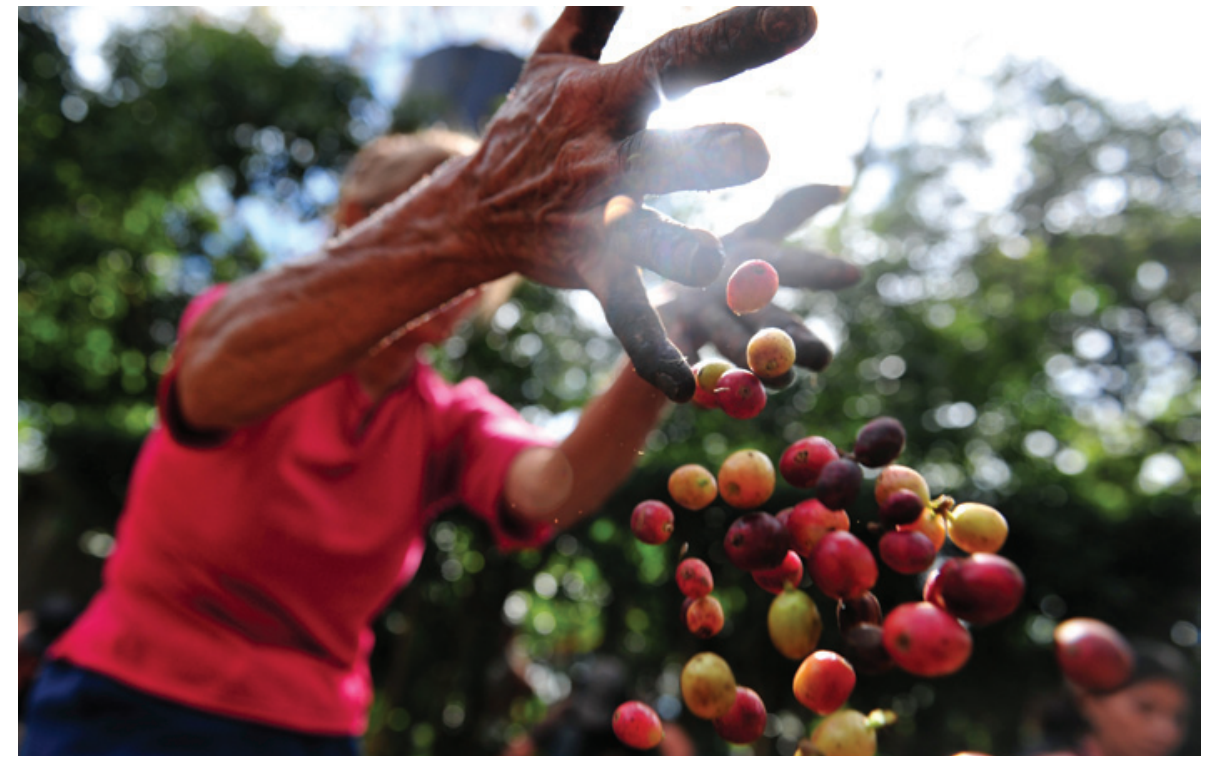

Coffee growers are worried that a fungal outbreak will affect the next harvest of coffee berries.

severe outbreaks were seen in Costa Rica in 1989 and Nicaragua in 1995, says Jacques Avelino, a plant pathologist at Costa Rica's Tropical Agricultural Research and Higher Education Center, based in San José.

But changes to management practices had brought the disease mostly under control. "Coffee rust was considered a solved problem by most of the coffee growers and coffee institutes of the region", says Avelino. "People didn't fear the disease." The outbreak may have taken hold because of patchy use and effectiveness of fungicides.

And in Africa, Noah Phiri, a plant pathologist working in Nairobi for the not-for-profit development organization CABI, says that rust has been causing ever-greater problems, although in Kenya, varieties resistant to the rust have held it at bay.

Colombia could be the closest to a solution. Marco Aurelio Cristancho, a researcher at Cenicafé, the National Centre for the Investigation of Coffee in Chinchiná, says that the government has supported research into developing resistant strains of coffee through crossbreeding. The introduction of resistant

Hemileia vastatrix 'rusts' the leaves of coffee plants. strains, together with improved weather monitoring to help predict rust outbreaks, has meant that fewer than $10 \%$ of plants now need to be treated with fungicide, down from $60 \%$ four years ago, Cristancho says. The government has also supported work on the genetics of both the fungus and the plant.

Research programmes have started in other countries, too. At the Federal Rural University of Rio de Janeiro in Brazil, Valdir Diola is working to isolate resistance genes in coffee and to find molecular markers that distinguish between different strains of the pathogen and that could be used to develop tailored strategies for its control. And in the United Kingdom, Harry Evans is working on the genome of $H$. vastatrix at CABI in Egham. In Nairobi, Phiri is using money from the intergovernmental agency the Common Fund for Commodities, as well as from Kenya, India, Rwanda, Uganda and Zimbabwe, to screen for resistant coffee plants and to analyse varieties of the pathogen.

"Scientists need to continuously develop resistant varieties in order to keep coffee leaf rust disease at bay," Phiri says. "Governments in coffee-growing countries need to take coffee research as a priority and provide necessary resources."

Cristancho says that other nations need to adopt an integrated approach similar to that of Colombia. "Unfortunately this effort is not mirrored in other regions of the world, where it is required to provide local solutions to the epidemics," he says. 